\title{
Retraction Note to: Recognition of pivotal instances from uneven set boundary during classification
}

\author{
A. Suresh ${ }^{1} \cdot$ R. Varatharajan ${ }^{2}$ \\ Published online: 5 April 2019 \\ (C) Springer Science+Business Media, LLC, part of Springer Nature 2019
}

\section{Retraction Note to: Multimed Tools Appl (2018) 77:27075-27088 https://doi.org/10.1007/s11042-018-5905-9}

The Editor-in-Chief has retracted this article [1], because it shows substantial overlap with a previously published article [2]. Author A. Suresh does not agree with the retraction. Author R. Varatharajan has not responded to correspondence about this retraction.

\section{References}

1. Suresh A, Varatharajan R (2018) Recognition of pivotal instances from uneven set boundary during classification. Multimed Tools Appl 77:27075. https://doi.org/10.1007/s11042-018-5905-9

2. Sathiaraj D, Triantaphyllou E (2013) On identifying critical nuggets of information during classification tasks. IEEE Trans Knowl Data Eng 25(6):1354-1367. https://doi.org/10.1109/TKDE.2012.112

Publisher's note Springer Nature remains neutral with regard to jurisdictional claims in published maps and institutional affiliations.

The online version of the original article can be found at https://doi.org/10.1007/s11042-018-5905-9

\section{A. Suresh}

prisu6esh@yahoo.com

R. Varatharajan

varathu21@yahoo.com

1 Department of Computer Science and Engineering, Nehru Institute of Engineering and Technology, Nehru Gardens, T.M. Palayam, Coimbatore 641 105, India

2 Department of Electronics and Communication Engineering, Sri Lakshmi Ammaal Engineering College, Chennai, India 